\title{
The European union's 2010 target: Putting rare species in focus
}

Benoît Fontaine*, Philippe Bouchet, Kees Van Achterberg, Miguel Angel Alonso-Zarazaga, Rafael Araujo, Manfred Asche, Ulrike Aspöck, Paolo Audisio, Berend Aukema, Nicolas Bailly, Maria Balsamo, Ruud A. Bank, Peter Barnard, Carlo Belfiore, Wieslaw Bogdanowicz, Tom Bongers, Geoffrey Boxshall, Daniel Burckhardt, Jean-Louis Camicas, Przemek Chylarecki, Pierangelo Crucitti, Louis Deharveng, Alain Dubois, Henrik Enghoff, Anno Faubel, Romolo Fochetti, Olivier Gargominy, David Gibson, Ray Gibson, Maria Soledad Gómez López, Daniel Goujet, Mark S. Harvey, Klaus-Gerhard Heller, Peter Van Helsdingen, Hannelore Hoch, Herman De Jong, Yde De Jong, Ole Karsholt, Wouter Los, Lars Lundquist, Wojciech Magowski, Renata Manconi, Jochen Martens, Jos A. Massard, Gaby Massard-Geimer, Sandra J. Mcinnes, Luis F. Mendes, Eberhard Mey, Verner Michelsen, Alessandro Minelli, Claus Nielsen, Juan M. Nieto Nafría, Erik J. Van Nieukerken, John Noyes, Thomas Pape, Hans Pohl, Willy De Prins, Marian Ramos, Claudia Ricci, Cees Roselaar, Emilia Rota, Andreas Schmidt-Rhaesa, Hendrik Segers, Richard Zur Strassen, Andrzej Szeptycki, Jean-Marc Thibaud, Alain Thomas, Tarmo Timm, Jan Van Tol, Wim Vervoort, Rainer Willmann

Muséum national d'Histoire naturelle, Département Systématique et Evolution - Malacologie - USM 602, Case postale N 51 , 57 Rue Cuvier, 75231 Paris, Cedex 05, France

A R T I C L E I N F O

Article history:

Received 1 June 2006

Received in revised form

19 April 2007

Accepted 17 June 2007

Available online 8 August 2007

Keywords:

Rarity

Endemism

Fauna Europaea

Invertebrate conservation

Extinct species

Europe
A B S T R A C T

The European Union has adopted the ambitious target of halting the loss of biodiversity by 2010. Several indicators have been proposed to assess progress towards the 2010 target, two of them addressing directly the issue of species decline. In Europe, the Fauna Europaea database gives an insight into the patterns of distribution of a total dataset of 130,000 terrestrial and freshwater species without taxonomic bias, and provide a unique opportunity to assess the feasibility of the 2010 target. It shows that the vast majority of European species are rare, in the sense that they have a restricted range. Considering this, the paper discusses whether the 2010 target indicators really cover the species most at risk of extinction. The analysis of a list of 62 globally extinct European taxa shows that most contemporary extinctions have affected narrow-range taxa or taxa with strict ecological requirements. Indeed, most European species listed as threatened in the IUCN Red List are narrow-range species. Conversely, there are as many wide-range species as narrow-range endemics in the list of protected species in Europe (Bird and Habitat Directives). The subset of biodiversity captured by the 2010 target indicators should be representative of the whole

* Corresponding author: Tel.: +331407931 02; fax: +331 40795771

E-mail address: fontaine@mnhn.fr (B. Fontaine).

0006-3207/\$ - see front matter (c) 2007 Elsevier Ltd. All rights reserved.

doi:10.1016/j.biocon.2007.06.012 
biodiversity in terms of patterns of distribution and abundance. Indicators should not overlook a core characteristic of biodiversity, i.e. the large number of narrow-range species and their intrinsic vulnerability. With ill-selected indicator species, the extinction of narrowrange endemics would go unnoticed.

(C) 2007 Elsevier Ltd. All rights reserved.

\section{Introduction}

The European Union has adopted the ambitious target of halting the loss of biodiversity by 2010 (European Union, 2001). It exceeds the target chosen by the nations of the world at the 2002 World Summit on Sustainable Development, which was to "achieve by 2010 a significant reduction of the current rate of biodiversity loss at the global, regional and national level as a contribution to poverty alleviation and to the benefit of all life on earth" (Convention on Biological Diversity, 2001a). In order to assess progress towards these targets, biodiversity should be monitored to know whether the rate of loss is increasing or decreasing, and eight indicators for immediate testing in seven focal areas were proposed by the CBD's seventh Conference of the Parties (COP7). In the focal area on "status and trends of the components of biological diversity" three indicators were proposed to assess progress towards the 2010 target (Convention on Biological Diversity, 2001b):

- Trends in extent of selected biomes, ecosystems and habitats.

- Trends in abundance and distribution of selected species.

- Coverage of protected areas.

In the same focal area, two other possible indicators are in development

- Change in status of threatened species.

- Trends in genetic diversity of domesticated animals, cultivated plants, and fish species of major socioeconomic importance.

Theoretically, these indicators provide a powerful way to assess progress. However, they could be difficult to implement, as data or standardized methodologies are lacking: even the assessment of the coverage of protected areas is hindered by the fact that protected areas do not have the same definitions in every country, and are sometimes difficult to attribute to IUCN Protected Area Management Categories (IUCN, 1994). Only two of these indicators are directly linked to species loss, being species-based, "Trends in abundance and distribution of selected species" and "Change in status of threatened species". Butchart et al. (2004) presented a method for producing indices based on the IUCN Red List to assess projected relative extinction risk of a species, and tested it for the world's birds and amphibians (Butchart et al., 2005). That was a major contribution to the development of the Red List indicator, which will measure changes in overall extinction risks for all species in taxa for which Red List data are available. However, at a global scale, only $0.1 \%$ of insect species, $3.1 \%$ of mollusc species and $1.3 \%$ of crustacean species have been evaluated, vs. $100 \%$ of bird species, $100 \%$ of amphibian species and $89.7 \%$ of mammal species (IUCN, 2006). Obviously, data are lacking for the assessment of whole invertebrate groups, as most invertebrate species have not been compared with the threat criteria: the Red List indicator, though powerful, is useless for species that have not been checked against the Red List criteria, i.e. most invertebrates, but also $91.9 \%$ of reptile species and $90.1 \%$ of fish species (IUCN, 2006). A number of groups are currently being assessed against the Red List (reptiles, freshwater fish, sharks, rays and chimeras and freshwater molluscs), and will be used to build a more robust aggregated Red List indicator (Butchart et al., 2005). However, this will still not cover most invertebrates, which represent the bulk of biodiversity, and one can ask whether this will even capture the main characteristics of biodiversity. Similarly, the "selected species" chosen for the indicator "Trends in abundance and distribution of selected species" should be representative of overall biodiversity, and not only of the better known species. Taking into account the neglected invertebrates in conservation policies is not only important for its own sake, but also because these species affect ecosystem functioning, although our knowledge of the linkages between biodiversity and ecosystem processes is very incomplete. Loss of biodiversity makes ecosystems vulnerable, and this may be particularly true for the neglected invertebrate taxa which, despite their minute size, play an important role in ecosystem functioning (Palmer et al., 1997; Tilman et al., 1997).

Although not directly correlated with vulnerability, rarity is a major determinant of a species' likelihood of extinction (Gaston, 1994; Yu and Dobson, 2000) and species usually become rare before going extinct (Dobson et al., 1995). There have been many attempts to recognize various forms of rarity (see Gaston (1994) for a compilation), but the most wellknown is Rabinowitz (1981). In this model, three factors can be combined to assess a species' rarity: range size (distribution), population size (demography) and habitat requirements (ecology). Species demonstrating geographical rarity are narrow-range endemics; species demonstrating demographic rarity are typically represented by large predators and species in decline; ecologically rare species are specialist species, the extreme case being single host parasitic species. The combination of these factors produces eight forms of rarity, the ninth group (large range, large population size and broad habitat requirements) being common species.

In the light of these theoretical considerations on rarity, we have assessed the reliability of the CBD 2010 target indicators at the scale of the European fauna, on the basis of the Fauna Europaea dataset. The Fauna Europaea program, funded by the European Commission for a period of 4 years (1 March 2000-1 March 2004) within the Fifth Framework 
Program (FP5), was designed to assemble a database of the scientific names and distribution of all living multi-cellular European land and fresh-water animals (Fauna Europaea, 2004). We address here the issue of the representativeness of the subsample of biodiversity captured by the 2010 target indicators at the European scale, with the insight given by Fauna Europaea: are the indicators currently used to assess the state of biodiversity really covering the species most at risk of extinction? In other words, the purpose of this paper is to assess whether the focus of the 2010 target indicators is on all biodiversity or on a part of it only: will these indicators give an accurate image of biodiversity loss in Europe?

\section{Methods}

This work was based on the Fauna Europaea list of non-marine animal species and subspecies in Europe (Fauna Europaea, 2004). This list covers all the terrestrial and freshwater fauna of Europe, i.e. ca. 130,000 species and ca. 14,000 subspecies. As subspecies have been included in Fauna Europaea for some groups only, our analyses were performed with species only. The area covered is the European mainland, plus the Macaronesian islands (excl. Cape Verde Is.), Cyprus, Franz Josef Land and Novaya Zemlya. Western Kazakhstan, Caucasus and the Asiatic part of Turkey are excluded. Three institutions have taken responsibility for the main complementary clusters of tasks: the University of Amsterdam (Zoological Museum Amsterdam) was in charge of the overall coordination and management, including the application of software and database tools to support these tasks; the University of Copenhagen (Zoological Museum) took care of the collation of the data and the creation of integrated datasets; and the Muséum national d'Histoire naturelle in Paris was responsible for the validation of the data sets. The data were gathered by 59 Group Coordinators, each of them being in charge of a taxonomic group, helped by 417 taxonomic specialists and associate specialists. All the taxonomic specialists and coordinators were selected as the key experts in their field. The Group Coordinators checked the consistency of the partial data sets, and independent validation was done in the Paris team. Moreover, for the Eastern European countries especially, a comparison was made with numerous local documents to inform the specialists about deviations. The final database of valid names, most used synonyms and distribution data should be regarded as a quality controlled product, representing currently available knowledge. For the purpose of the present analysis, a database was built to conveniently handle this huge amount of taxonomic and distribution data, the raw data being provided as Microsoft Excel sheets by the Fauna Europaea Bureau in Amsterdam.

We considered legal protection status at the European level only, with texts giving a real protection status, i.e. allowing a legal action to be taken if needed. In this framework, the only legal documents really protecting species are the Council Directive on the conservation of wild birds (Birds Directive) and the Council Directive on the conservation of natural habitats and of wild fauna and flora (Habitat Directive).

The species lists given in the Appendix of the directives were integrated into the database. Queries were generated in the Fauna Europaea database to obtain a list of all the protected species in Europe, as some species are protected at a supra-specific level (all European birds are protected by the Bird Directive for instance). This list was double-checked by hand in order to track mistakes.

Distribution data were taken from the Fauna Europaea database, i.e. presence/absence in each Fauna Europaea geographical unit. The geographical units employed in Fauna Europaea were countries, large islands or archipelagos, thus ranging from several hundreds thousands of square kilometers (France, Germany) to a few square kilometers (Selvagen Islands). Data on the distribution of Red Listed species were taken from the Red List, as Fauna Europaea does not give precise distribution data outside Europe (many European Red Listed species also range outside Europe).

The IUCN Red List is widely acknowledged as the most objective and comprehensive compilation of threatened and extinct species worldwide (Lamoreux et al., 2003), having no legal status and being compiled by thousands of scientists. As such, it is the best available basis for the indicator on "Change in status of threatened species". The list of European threatened species was thus extracted from the IUCN Red List website (IUCN, 2006), selecting the species classified as Critically Endangered, Endangered and Vulnerable for each European country. Threatened species from Russia and Turkey were checked individually to remove those occurring only in the Asian part of these countries. The list of extinct species was compiled from the 2006 IUCN Red List and from the literature, with the help of the Fauna Europaea Group Coordinators.

Each of the 804 bird species present in Fauna Europaea had to be listed as protected in our database, as the Bird Directive states that populations and habitats of all species of naturally occurring birds in the wild state in the European territory should be maintained (Articles 1, 2 and 3). However, the Fauna Europaea bird list does not comply with Fauna Europaea geographic range. In particular, it includes species from the Caucasus, Middle East and North Africa which extend beyond the Fauna Europaea zone. In order to be consistent with the other groups, these species have been excluded from our dataset. Data on species range of birds were taken from Beaman and Madge (1998).

The Fauna Europaea bird list also contains Asian or Nearctic vagrants that are seen only exceptionally in Europe. These species have been excluded from the dataset used in this study, for three reasons:

- Many of them are listed in Fauna Europaea as occurring in one European country only, because they have been recorded in Europe only once. Keeping them would produce a bias in the analysis of endemic species in Europe (97 bird species occurring in one European country only, as given by the Fauna Europaea database, definitely does not reflect the fact that only 19 bird species are European single country endemics).

- Given the high number of birdwatchers in Europe, birds are the only group with such coverage, and are much better known than any other taxon in Europe. A vagrant Diptera from America would hardly be noticed if it was blown up 
by a storm to the Scilly Islands, unlike an American warbler. As it is impossible to include vagrant species in other taxa, vagrant bird species should be removed from the dataset to avoid biases.

- These vagrant birds do not breed in Europe, nor are regular migrants in Europe: strictly speaking, they do not belong to the European fauna.

Vagrant bird species were identified from Beaman and Madge (1998) and discarded.

\section{Results}

\subsection{Endemism in the European fauna}

The vast majority of European species have a restricted range (Fig. 1): $37 \%$ of European species are present in [part of] one Fauna Europaea geographical unit only, and half of the species are present in [part of] one or two Fauna Europaea geographical units. Moreover, species restricted to mountain ranges (e.g. Pyrenees, Alps, Carpathians, Rhodope mountains) or lakes (e.g. Lake Ohrid, Lake Constance, Lake Neusiedler or Lake Prespa) that are shared by two or three countries, which are narrow-range endemics, appear in this figure as present in two or even three Fauna Europaea geographical units. Fauna Europaea cannot provide better estimates of range size, let alone areas of occupancy: the area of its large geographical units overestimates the true areas of occupancy of species, as most endemic species do not occur in the whole of the geographical unit.

More than $99 \%$ of the species present in one Fauna Europaea geographical unit only are invertebrates, for which distributional data are sometimes inadequate: an extreme situation is the case of species only known from the holotype and the type locality (Stork, 1997). In these cases, endemism is most probably an artefact due to a lack of knowledge. In order to account for this bias, the same estimates of endemism were calculated for the best known groups: vertebrates, Mollusca, Coleoptera Carabidae, Lepidoptera, Odonata and Orthoptera (Fig. 2): the pattern is still the same as for the whole fauna: $35 \%$ of the "well-known" species are present in [part of] one Fauna Europaea geographical unit only vs. $37 \%$ in Fig. 1. Even for well-known taxa, endemism is widespread. When terrestrial vertebrates only are considered, $13 \%$ are endemic to a single Fauna Europaea geographical unit, and 19\% from one or two Fauna Europaea geographical units, but $11 \%$ are present in more than 59 Fauna Europaea geographical units (Fig. 3).

Fauna Europaea lists 7070 species endemic from European islands covering less than $10,000 \mathrm{~km}^{2}$ (Table 1 ). At most, the range of these species cannot exceed the area of the islands. These very rough distribution data are nevertheless enough to characterize thousands of European species as narrowrange endemics sensu Harvey (2002), i.e. naturally occurring on less than $10,000 \mathrm{~km}^{2}$. It should be noted that there are many more islands housing single-island endemics in Europe than those listed in Table 1, e.g. Greek islands which are not treated individually in Fauna Europaea. Most of these single-island endemics are invertebrates; however, 11 European bird taxa have a range of $4000 \mathrm{~km}^{2}$ or less, and a further eight have a range of $8000 \mathrm{~km}^{2}$ or less, most of them in the Macaronesian islands (C. Roselaar, unpub. data).

At a fine scale, data on the range size of narrow-range invertebrates are scarce. An approximation of the maximum size of the range of endemic species can be given by the cumulative surface of the smallest territorial division known

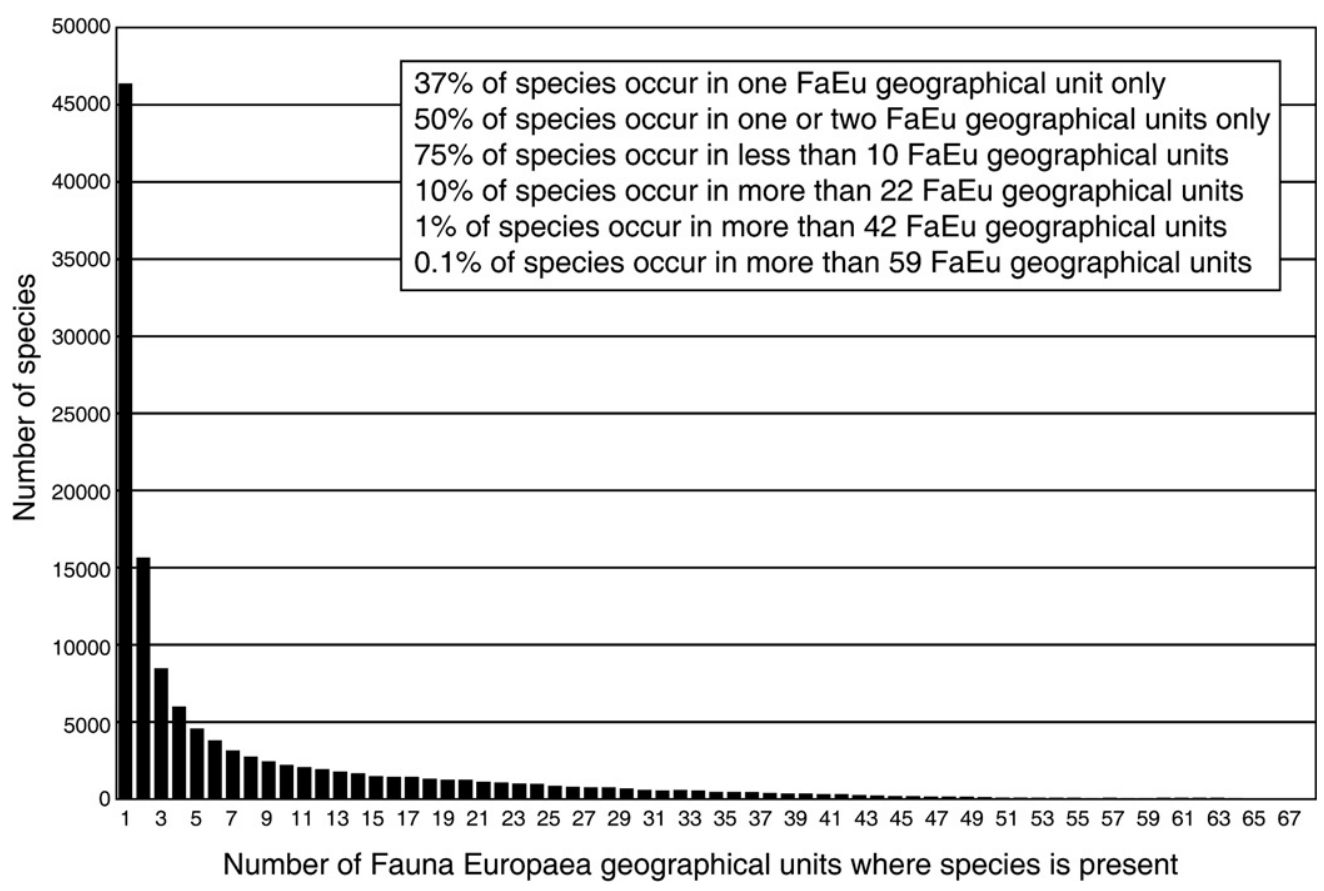

Fig. 1 - Geographical rarity: number of species present in any given number of Fauna Europaea geographical units. Based on Fauna Europaea distribution data. 


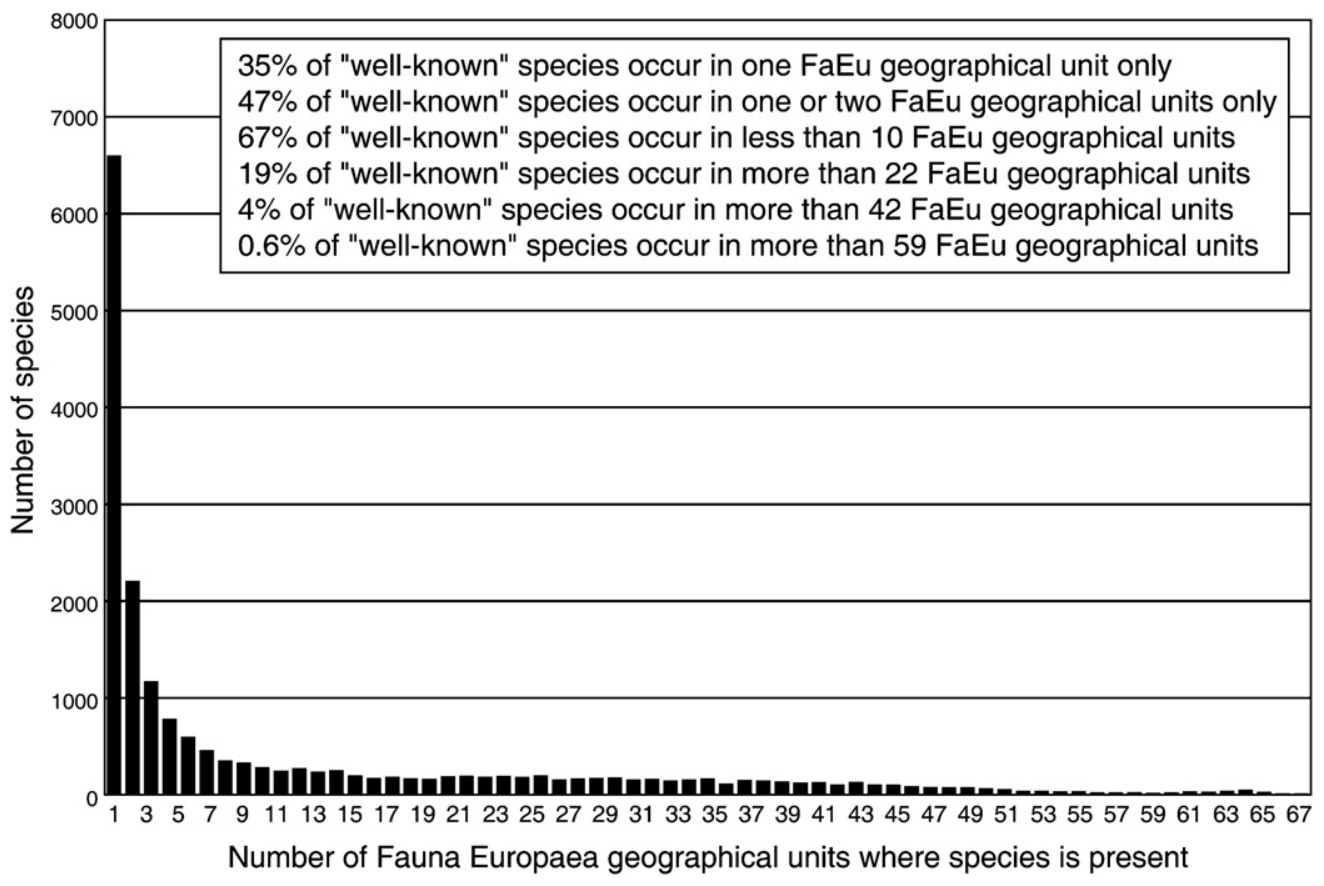

Fig. 2 - Geographical rarity: number of species present in any given number of Fauna Europaea geographical units, for the best known groups: vertebrates, Mollusca, Coleoptera Carabidae, Lepidoptera, Odonata, Orthoptera. Based on Fauna Europaea distribution data.

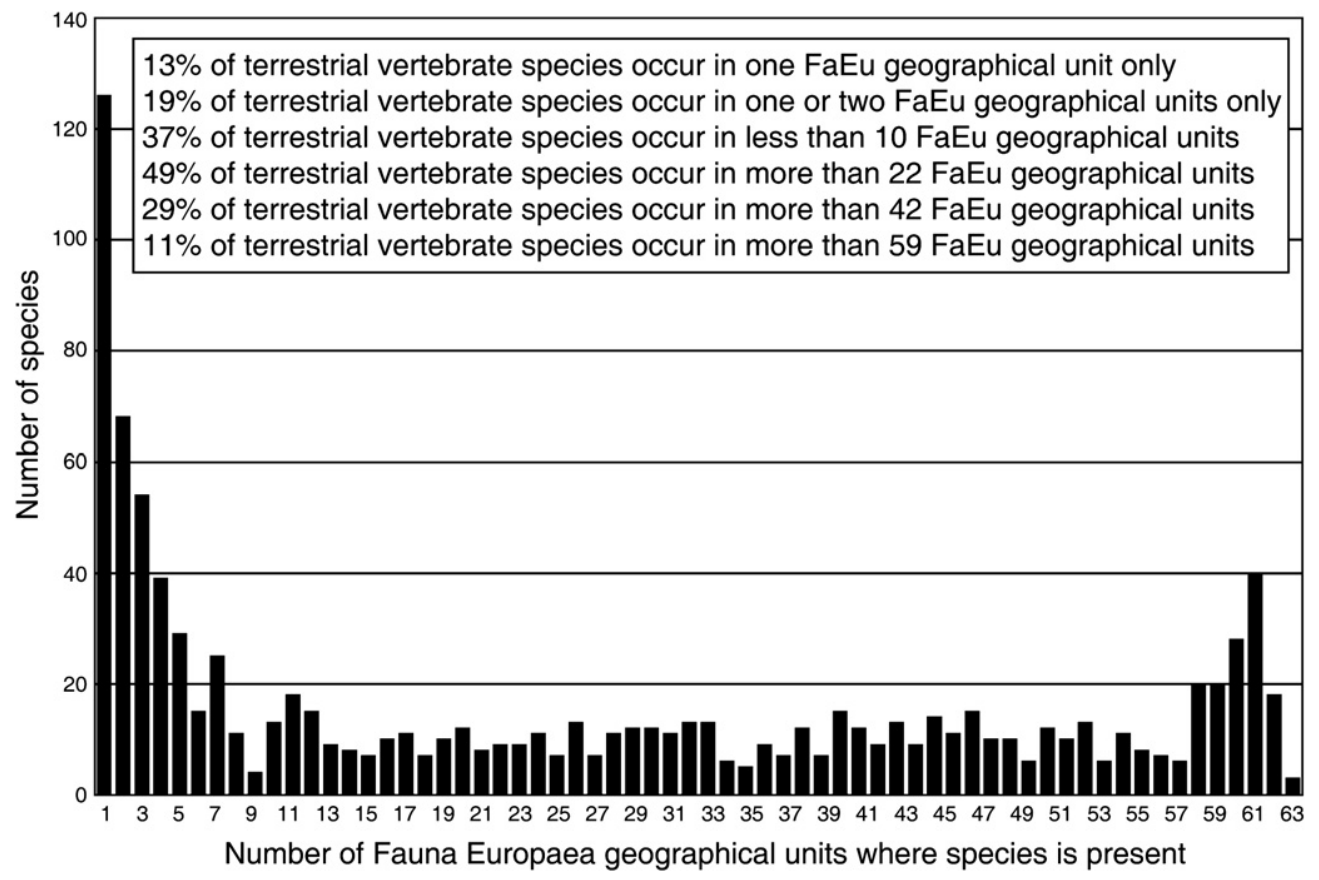

Fig. 3 - Geographical rarity: number of species present in any given number of Fauna Europaea geographical units, for vertebrates excluding fish. Based on Fauna Europaea distribution data.

to cover their total distribution range. This is a very conservative estimate, as these species occur at a few sites of occupancy, and not over all of the territorial division area: these figures must be considered as a maximum range size. For instance, 46 Collembola taxa occurring in Ariège province (Pyrénées mountains, France) are Pyrenean endemics. They are known from 1 to 19 "communes", the smallest territorial divi- sion in France, usually covering a few thousands hectares: their maximum range size is far below $10,000 \mathrm{~km}^{2}$ (Deharveng, unpubl. data). For the 12 Collembola taxa endemic from Ariège province, this rough calculation on "commune" area gives a maximum range size varying between $5.73 \mathrm{~km}^{2}$ and $199.90 \mathrm{~km}^{2}$ (Fig. 4). It should be noted that the Pyrénées area is one of the best-known region in Europe for Collembola, 


\begin{tabular}{|c|c|c|}
\hline Island or archipelago & $\begin{array}{l}\text { Number of } \\
\text { endemic species }\end{array}$ & $\begin{array}{l}\text { Area } \\
\left(\mathrm{km}^{2}\right)\end{array}$ \\
\hline Madeira & 956 & 797 \\
\hline Azores & 278 & 2305 \\
\hline Canary Islands & 3236 & 7272 \\
\hline Balearic Islands & 308 & 5014 \\
\hline Corsica & 552 & 8723 \\
\hline Malta & 104 & 316 \\
\hline Crete & 719 & 8313 \\
\hline Cyprus & 917 & 9250 \\
\hline
\end{tabular}

and that these taxa were specifically searched for in several localities. Even if new field searches might extend their known range, they can be considered as real local endemics, unlike other collembolan taxa which have been found in the whole region and further.

\subsection{Extinct and threatened species}

Table 2 shows the documented extinctions of European taxa since 1500. Among the 62 extinct taxa, 11 were wide-range taxa (including three insects, four fish, one bird and three mammals), the others being endemic to one country, or narrow-range endemics shared by two or three countries. The recorded extinctions of narrow-range taxa occurred mainly in mountain ranges (Alpine arc, Pyrenees, Balkans), and on islands (Fig. 5).
Altogether, 560 European terrestrial or freshwater species are listed as endangered (categories Critically endangered, Endangered and Vulnerable) in the 2006 IUCN Red List (IUCN, 2006). Of these, $31.1 \%$ are molluscs, $30.9 \%$ are arthropods and $38.0 \%$ are vertebrates, and $65.0 \%$ are endemic to one country (Fig. 6). Among these endemic species, 31.6\% are arthropods and $44.8 \%$ are molluscs. At the other end, among threatened species with a large range (present in 21-138 countries), $79.5 \%$ are vertebrates. Geographically, threatened species are spread all over Europe (Fig. 5), the three countries having the largest number of threatened species being among the most species-rich countries in Europe (Italy, France and Spain - see http://www.faunaeur.org/statistics.php). Countries with a lower number of threatened species either are countries with a relatively low biodiversity (northern Europe) or are probably under-studied (Balkans). Even in Europe, with 560 species listed as threatened, the Red List is far from complete, as most invertebrate species have not been assessed. Moreover, it lists only 14 extinct species in Europe, when there are at least 62 (Table 2). Despite this global under-coverage, European invertebrates are "reasonably" represented in the Red List, as they account for almost two thirds of the European species listed (at a worldwide scale, invertebrates represent only $27.2 \%$ of the animal listed in the Red List (IUCN, 2006)).

\subsection{Protected species}

The Bird and Habitat directives give a protection status to 1140 animal species, including 986 vertebrates and 154 invertebrates (Table 3 ). This represents $64.8 \%$ of the vertebrates

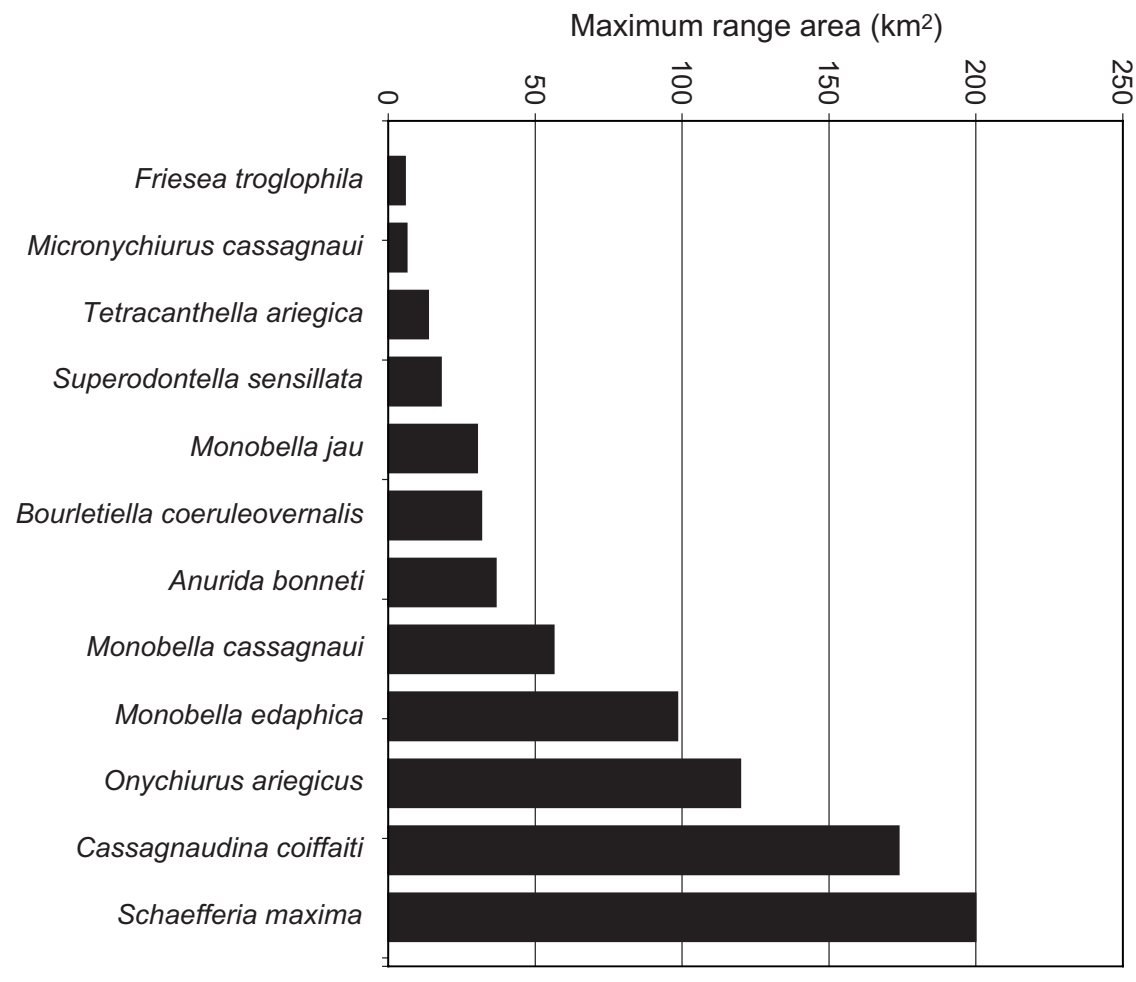

Fig. 4 - Endemic Collembola from Ariege province (France): maximum range size $\left(\mathbf{k m}^{2}\right)$ given by the cumulated surface of the smallest territorial division known to cover their total distribution range (Deharveng unpubl. data). 
Table 2 - European globally extinct taxa

\begin{tabular}{|c|c|c|c|c|}
\hline Taxon & Group & Red List & Range & Source \\
\hline Belgrandia varica (J. Paget 1854) & Gastropoda & No & France & Falkner et al. (2002) \\
\hline Belgrandiella boetersi (P. Reischütz \& Falkner 1998) ${ }^{\mathrm{a}}$ & Gastropoda & Yes & Austria & IUCN (2006) \\
\hline Bythiospeum pfeifferi (Clessin 1890) ${ }^{b}$ & Gastropoda & No & Austria & R. Bank unpub. data \\
\hline Caseolus calvus galeatus (R.T. Lowe 1862) & Gastropoda & No & Madeira & R. Bank unpub. data \\
\hline Discula lyelliana (R.T. Lowe 1852) & Gastropoda & No & Madeira (Deserta Grande) & R. Bank unpub. data \\
\hline Discula tetrica (R.T. Lowe 1862) ${ }^{c}$ & Gastropoda & No & Madeira (Bugio) & R. Bank unpub. data \\
\hline Discus engonatus (Shuttleworth 1852) & Gastropoda & No & Canary Islands (Tenerife) & R. Bank unpub. data \\
\hline Discus retextus (Shuttleworth 1852) & Gastropoda & No & Canary Islands (La Palma) & R. Bank unpub. data \\
\hline Discus textilis (Shuttleworth 1852) & Gastropoda & No & Canary Islands (La Palma) & R. Bank unpub. data \\
\hline Geomitra delphinuloides (R.T. Lowe 1860) ${ }^{c}$ & Gastropoda & No & Madeira & R. Bank unpub. data \\
\hline Geomitra grabhami (Wollaston 1878) & Gastropoda & No & Madeira (Deserta Grande) & R. Bank unpub. data \\
\hline Graecoanatolica macedonica Radoman \& Stankovic 1979 & Gastropoda & Yes & Greece, Macedonia & IUCN (2006) \\
\hline Gyralina hausdorfi Riedel 1990 & Gastropoda & No & Greece & R. Bank unpub. data \\
\hline Janulus pompylius (Shuttleworth 1852) & Gastropoda & No & Canary Islands (La Palma) & R. Bank unpub. data \\
\hline Keraea garachicoensis (Wollaston 1878) & Gastropoda & No & Canary Islands (Tenerife) & R. Bank unpub. data \\
\hline Leiostyla abbreviata (R.T. Lowe 1852) ${ }^{c}$ & Gastropoda & No & Madeira & R. Bank unpub. data \\
\hline Leiostyla gibba (R.T. Lowe 1852) & Gastropoda & No & Madeira & R. Bank unpub. data \\
\hline Leiostyla lamellosa (R.T. Lowe 1852) & Gastropoda & Yes & Madeira & IUCN (2006) \\
\hline Leptaxis simia hyaena (R.T. Lowe 1852) & Gastropoda & No & Madeira (Bugio) & R. Bank unpub. data \\
\hline Ohridohauffenia drimica (Radoman 1964) & Gastropoda & Yes & Lake Ohrid, Serbia and Montenegro & IUCN (2006) \\
\hline Parmacella gervaisii Moquin-Tandon 1850 & Gastropoda & No & France & Falkner et al. (2002) \\
\hline Pseudocampylaea loweii (A. Férussac 1835) & Gastropoda & Yes & Madeira & IUCN (2006) \\
\hline Zonites embolium elevatus Riedel \& Mylonas 1997 & Gastropoda & No & Greece (Dodecanese Islands) & R. Bank unpub. data \\
\hline Zonites santoriniensis Riedel \& Norris 1987 & Gastropoda & No & Greece (Cyclades Islands) & R. Bank unpub. data \\
\hline Zonites siphnicus Fuchs \& Käufel 1936 & Gastropoda & No & Greece (Cyclades Islands) & R. Bank unpub. data \\
\hline Pseudoyersinia brevipennis (Yersin 1860) & Mantodea & No & France & Voisin (2003) \\
\hline Anonconotus apenninigenus (Targioni-Tozzetti 1881) & Orthoptera & No & Italy & Galvagni (2004), K.G. Heller unpub. data \\
\hline Oemopteryx loewii (Albarda 1889) & Plecoptera & No & $\begin{array}{l}\text { Austria, Bulgaria, Czech Republic, Germany, } \\
\text { Hungary, Netherlands, Poland, Slovakia, Ukraine }\end{array}$ & Zwick (2004) \\
\hline Taeniopteryx araneoides Klapálek 1902 & Plecoptera & No & Czech Republic, Germany, Hungary, Slovakia & Zwick (2004) \\
\hline Hydraena sappho Janssens 1965 & Coleoptera & No & Greece & Audisio et al. (1996) \\
\hline Meligethes salvan Audisio et al. (2003) & Coleoptera & No & Italy & Audisio et al. (2003), P. Audisio unpub. data \\
\hline Siettitia balsetensis Abeille de Perrin 1904 & Coleoptera & Yes & France & IUCN (2006) \\
\hline Hydropsyche tobiasi Malicky 1977 & Trichoptera & Yes & Germany & IUCN (2006) \\
\hline Pieris brassicae wollastoni (Butler 1886) & Lepidoptera & No & Madeira & O. Karsholt unpub. data \\
\hline Thyreophora cynophila (Panzer 1798) & Diptera & No & France, Germany, Switzerland & Séguy (1950), Menier (2002) \\
\hline Squalius ukliva Heckel $1843^{\mathrm{d}}$ & Pisces & Yes & Croatia & IUCN (2006) \\
\hline Coregonus bezola Fatio 1888 & Pisces & No & Lake Bourget (France) & Kottelat (1997) \\
\hline Coregonus confusus Fatio 1885 & Pisces & No & Lake Morat (Switzerland) & Kottelat (1997) \\
\hline Coregonus fera Jurine 1825 & Pisces & No & Lake Geneva (France, Switzerland) & Kottelat (1997) \\
\hline Coregonus gutturosus (Gmelin 1818) & Pisces & No & Lake Konstanz (Austria, Germany, Switzerland) & Kottelat (1997) \\
\hline Coregonus hiemalis Jurine 1825 & Pisces & No & Lake Geneva (France, Switzerland) & Kottelat (1997) \\
\hline Coregonus hoferi Berg 1932 & Pisces & No & Lake Chiemsee (Germany) & M. Kottelat, unpub. data \\
\hline Coregonus oxyrinchus (Linnaeus 1758) & Pisces & No & North Sea Basin & Freyhof and Schöter (2005) \\
\hline Coregonus restrictus Fatio 1885 & Pisces & No & Lake Morat (Switzerland) & Kottelat (1997) \\
\hline
\end{tabular}




\section{Table 2 - continued}

\begin{tabular}{|c|c|c|c|c|}
\hline Taxon & Group & Red List & Range & Source \\
\hline Eudontomyzon (?)sp. & Pisces & No & Ukraine, Russian Federation & Kottelat et al. (2005) \\
\hline Gasterosteus crenobiontus Bacescu \& Mayer 1956 & Pisces & No & Romania & Kottelat (1997) \\
\hline Knipowitschia cameliae Nalbant \& Otel 1995 & Pisces & No & Romania & Nalbant and Otel (1995) \\
\hline Romanogobio antipai (Banarescu, 1953) & Pisces & No & Romania, mouth of River Danube & Banarescu (1994) \\
\hline Salmo schiefermuelleri Bloch 1784 & Pisces & No & Baltic Sea, Austria, Hungary & Kottelat (1997) \\
\hline Salvelinus neocomensis Freyhof \& Kottelat 2005 & Pisces & No & Lake Neuchatel (Switzerland) & Freyhof and Kottelat (2005) \\
\hline Salvelinus profundus (Schillinger 1901) & Pisces & No & Lake Konstanz (Austria, Germany, Switzerland) & Kottelat (1997) \\
\hline Stenodus leucichthys (Güldenstädt 1772) ${ }^{\mathrm{e}}$ & Pisces & No & Caspian Sea Basin & M. Kottelat, unpub. data \\
\hline Gallotia auaritae Mateo, García Márquez, López Jurado \& Barahona, 2001 ${ }^{\mathrm{f}}$ & Reptilia & Yes & Canary Islands & IUCN (2006) \\
\hline Haematopus meadewaldoi Bannerman 1913 & Aves & Yes & Canary Islands & IUCN (2006) \\
\hline Pinguinus impennis (Linnaeus 1758) & Aves & Yes & Iceland, Ireland, United Kingdom, Denmark & IUCN (2006) \\
\hline Saxicola dacotiae murielae Bannerman, 1913 & Aves & No & Canary Islands & Fuller (1987) \\
\hline Capra pyrenaica lusitanica Schlegel 1872 & Mammalia & No & Portugal, Spain & Fauna Europaea \\
\hline Capra pyrenaica pyrenaica Schinz 1838 & Mammalia & Yes & Spain & IUCN (2006) \\
\hline Bison bonasus hungarorum Kretzoi 1946 & Mammalia & No & Hungary, Romania, Slovakia, Ukraine & Pucek et al. (2004) \\
\hline Bos primigenius Bojanus 1827 & Mammalia & No & Most of Europe & Fauna Europaea \\
\hline Equus ferus Boddaert $1785^{\circ}$ & Mammalia & Yes & $\begin{array}{l}\text { Poland, Germany, Lithuania, Belarus, Russian } \\
\text { Federation, Ukraine }\end{array}$ & IUCN (2006) \\
\hline Prolagus sardus (Wagner 1832) & Mammalia & Yes & Corsica, Sardinia & IUCN (2006) \\
\hline
\end{tabular}

The column "Red List" indicates whether the taxon is listed as extinct in the IUCN Red List.

Note: The 2006 IUCN Red List lists Bythinella intermedia Mahler 1950 (Gastropoda) as extinct. However, this is a synonym of Bythinella austriaca (Frauenfeld 1857), which is not extinct

(http://www.faunaeur.org/full_results.php?id=269218). It also lists Telestes turskyi (Heckel 1843) as extinct, but M. Kottelat (pers. comm.) considers it as still extant, though critically endangered,

and did not list it as extinct in his 1997 checklist (Kottelat, 1997); this species is considered as an insufficiently documented to be classified as extinct by Harrison and Stiassny (1999).

Chondrostoma scodrense Elvira 1987, said to be extinct (Crivelli and Rosecci 1994 in Kottelat, 1997), is probably still extant (M. Kottelat pers. comm.). These taxa were not included in the present table.

a Listed as Belgrandiella intermedia in the Red list. We follow here Fauna Europaea.

b Listed as Endangered in the Red List.

c Listed as Critically Endangered in the Red List.

d Listed as Telestes ukliva in the Red list. We follow here Fauna Europaea.

e Apparently extinct in the wild, the only breeding populations are captive.

f This taxon is not included in Fauna Europaea, as it was originally described as a subspecies of Gallotia simonyi, but was elevated at species level in 2003 (Afonso and Mateo, 2003).

$\mathrm{g}$ Extinct in the wild but still survives in captivity. 


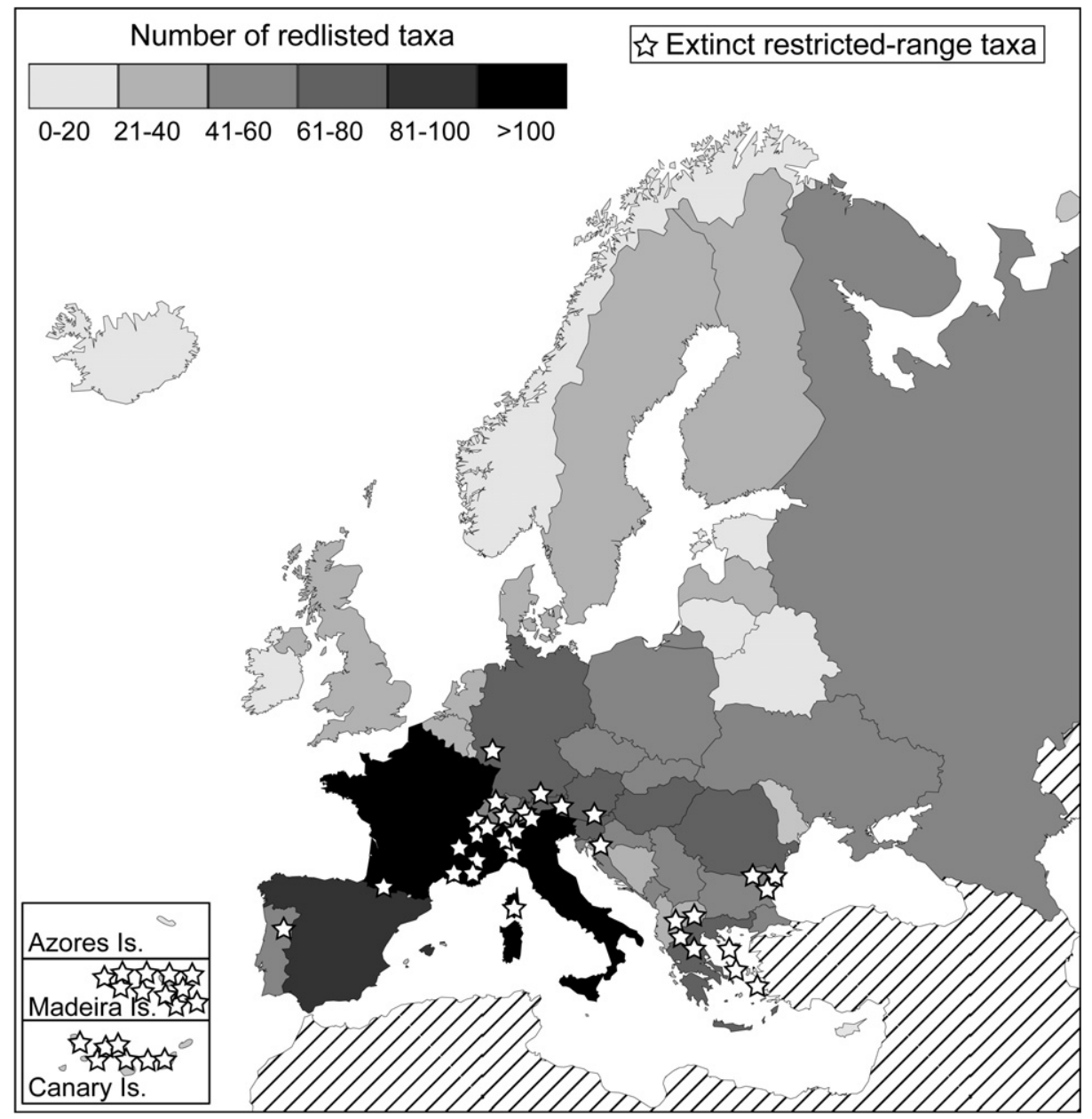

Fig. 5 - Distribution of extinct and threatened (critically endangered, endangered and vulnerable) species in Europe (data extracted from the 2006 IUCN Red List). Species present in more than one country are counted for each of these countries. Stars indicate the approximate location of narrow-range globally extinct taxa.

and $0.1 \%$ of the invertebrates present in Europe. Among protected invertebrates, $24 \%$ are Mollusca, $30 \%$ are Lepidoptera, and $23 \%$ are Coleoptera.

Out of the 560 European Red Listed non-marine species, 397 are not included in the directives (306 invertebrates and 91 vertebrates). On the other hand, 977 taxa are protected by the directives but are not Red Listed (864 vertebrates and 113 invertebrates) and 163 taxa are Red Listed and protected, i.e. 122 vertebrates and 41 invertebrates (Fig. 7). Three extinct invertebrates (the gastropods Leiostyla lamellosa, L. gibba and L. abbreviata) are listed in Appendix II of the Habitat Directive.

Two subspecies of Lepidoptera (Gortyna borelii lunata and Hesperia comma catena) and one mammal subspecies (Cervus elaphus corsicanus) are listed in the directives but not in Fauna Europaea. Even if their taxonomic validity is debatable, they represent small populations, and the governmental advisors have considered that they have a conservation value (Bouchet, 2006).

Fig. 8 presents the extent of occurrence of taxa listed in the directives. It does not follow the same abundance-rank pattern as in Figs. 1 and 2: a large proportion (11\%) of protected taxa are endemic to one Fauna Europaea geographical unit, but a similar proportion (12\%) of the protected taxa has a large range, i.e. occurring in more than 58 Fauna Europaea geographical units. All these wide-range taxa are birds. Among protected taxa endemic to one Fauna Europaea geographical unit, $25 \%$ are invertebrates.

\section{Discussion}

The Fauna Europaea dataset shows that a high proportion of the European species are single country endemics. Narrowrange species are especially vulnerable and a significant proportion of documented extinctions in Europe were of taxa with a restricted range. Rarity, and particularly geographical rarity, should then be considered when choosing indicator species for the 2010 target.

\subsection{Geographical rarity}

Geographical rarity (extent of occurrence) cannot be defined the same way for all species. In its assessment of the threat status of the birds of the world (Birdlife International, 2000), as well as in the prioritization of conservation areas (Stattersfield et al., 1998), Birdlife defines an endemic bird as a species whose range is below $50,000 \mathrm{~km}^{2}$, i.e. an area larger than 


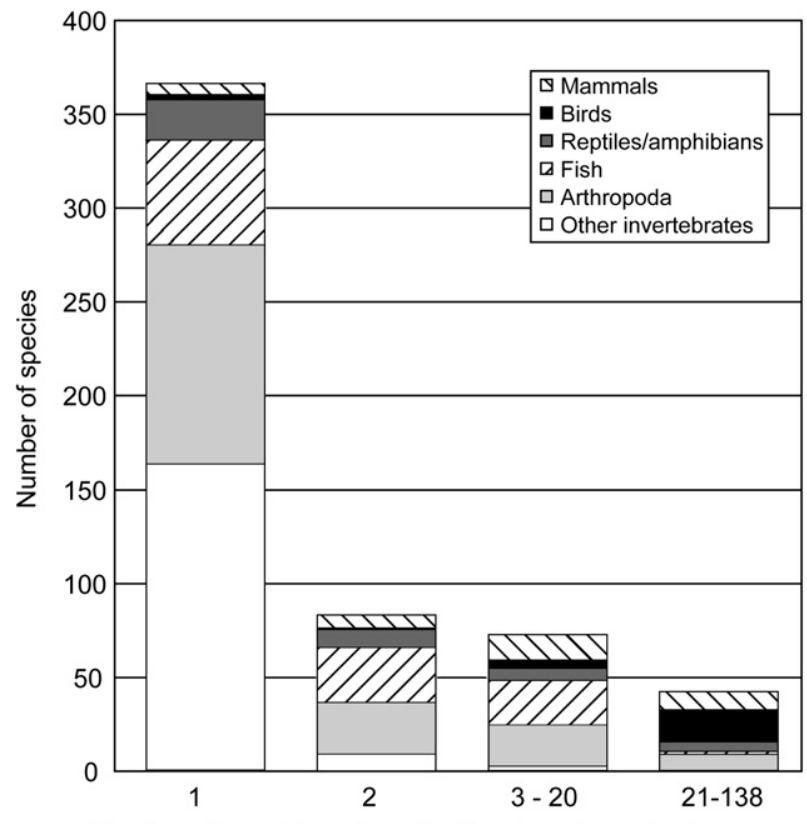

Number of countries where the threatened species is present

Fig. 6 - European species listed as threatened (critically endangered, endangered and vulnerable) in the 2005 IUCN Red List and the number of countries where they occur (distribution data as given in the IUCN Red List).

Table 3 - Species listed in the Bird Directive and Habitat Directive

\begin{tabular}{lcc} 
Group & $\begin{array}{c}\text { No. of species listed } \\
\text { in directives }\end{array}$ & $\begin{array}{c}\% \text { of the European } \\
\text { fauna }\end{array}$ \\
\hline Mammals & 95 & 37.4 \\
Birds & 533 & 100 \\
Reptiles & 82 & 53.2 \\
Amphibians & 51 & 66.2 \\
Fish & 225 & 44.8 \\
Lepidoptera & 46 & 0.5 \\
Coleoptera & 36 & 0.1 \\
Other insecta & 28 & 0.05 \\
Mollusca & 37 & 1.2 \\
Other invertebrates & 7 & 0.02 \\
All vertebrates & 986 & 64.8 \\
All invertebrates & 154 & 0.1 \\
\hline
\end{tabular}

Slovakia. This threshold has proven useful for large species such as birds and practical for conservation policies, but it is at least one order of magnitude too large to mark endemism in invertebrates, as shown by the data on Collembola. Patterns of distribution with very small ranges are probably common among invertebrates: at a worldwide scale, Solem (1984) predicted a median range of less than $100 \mathrm{~km}^{2}$ for all land snail species, and probably less than $50 \mathrm{~km}^{2}$. With a threshold of $10,000 \mathrm{~km}^{2}$, Harvey (2002) found that narrow-range endemism was widespread among several groups of Australian invertebrates, and was restricted to taxa with low vagility, highly seasonal life cycles, and restricted habitat usage.

Beside Collembola, many examples of narrow-range endemism are known from the European fauna. Narrow-range

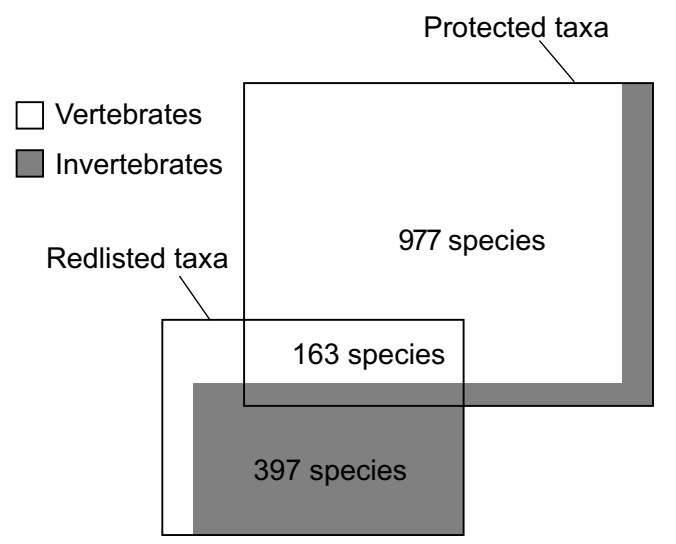

Fig. 7 - Protected species (Bird and Habitat Directives) and Red Listed species in Europe.

endemic species occur in many lakes (Kottelat, 1997; WCMC, 1998) as well as within terrestrial species (e.g. Lumaret et al., 1996). In particular, cave species are well-known to have a very high level of endemism, often being restricted to few caves in the same area (Mauries, 1986; Deharveng and Thibaud, 1989; Heurtault, 1994).

European globally extinct taxa give an insight into the vulnerability of narrow-range taxa. For instance, the gastropod Belgrandia varica was endemic to the floodplains of the Var estuary in southern France. This area has drastically changed during the 20th century, due to urbanisation, and the species has never been found since 1910, despite targeted searches, and is considered extinct (Falkner et al., 2002). Based on a specimen collected in 1912, the beetle Meligethes salvan was described from a small basin in the Italian Alps. The area was almost entirely destroyed by works associated with a hydroelectric power plant in the 1970s, and despite several attempts, no new specimen of this species has ever been found (Audisio et al., 2003). Another example is Romanichthys valsanicola, a fish that was restricted to the upper reaches of Arges, Vilsan and Doamnei rivers in Romania. In 1992, it was only found on $1 \mathrm{~km}$ of the Vilsan river, due to habitat degradation and water pollution; it might be extinct today (Perrin et al., 1993).

There are far too few experts on many invertebrate groups to obtain a comprehensive picture of extinctions. Most invertebrate extinctions are likely to be overlooked (Centinelan extinctions sensu Wilson (1992)) even in well-studied areas such as Europe, mainly because of a lack of knowledge and monitoring of these taxa (Dunn, 2005). The beetle Meligethes salvan was believed to be extinct ca. 40 years after its possible extinction (Audisio et al., 2003), and the beetle Hydraena sappho was declared extinct some 25-30 years after its actual extinction (Audisio et al., 1996). Moreover, the Mediterranean region is a centre of endemism (Myers et al., 2000), but has experienced serious degradations due to urbanisation, altered fire regimes and agriculture: in Europe, it is probably an area where Centinelan extinctions have occurred. For these reasons, the 62 extinct taxa for Europe presented in Table 2 are probably an underestimate. Even when the extinction is confirmed by the experts, the information is still often ignored to the wider community: 48 extinct European taxa, including 28 


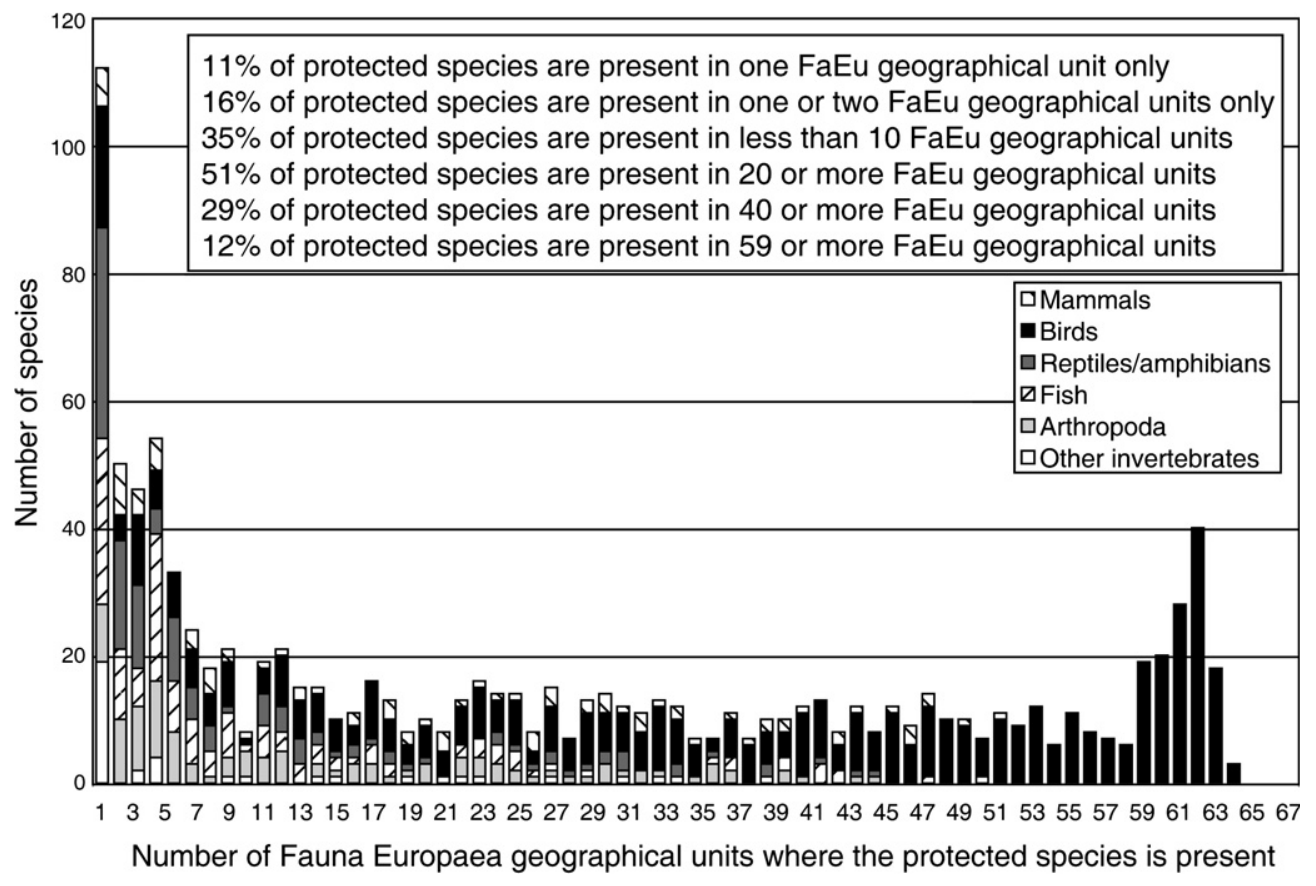

Fig. 8 - Number of protected species (Bird and Habitat Directives) present in any given number of Fauna Europaea geographical units.

invertebrates, are not included in the Red List (Table 2). Despite this incomplete image of extinctions, the list of European extinct taxa shows that geographically rare taxa are by far the most at risk of extinction (51 extinct taxa out of 62 had a restricted range). There could be a bias there, as it is easier to assess extinction of a narrow-range species than of a demographically rare species with a large range. However, it does not undermine the fact that geographically rare species must be prioritized for the assessment of the 2010 target.

In order to be representative of the European fauna, the subset of European species captured by the 2010 target indicators should include a statistically significant proportion of narrow-range species. Popular groups such as butterflies, dragonflies, bumblebees, hoverflies and ants should be investigated for use as potential indicators (Thomas, 2005). Cave species should also be represented in the indicators, as most of them are local endemics. We emphasize that as many taxonomic groups as possible should be represented, taking into account geographical rarity.

\subsection{Ecological rarity}

Among the extinct taxa in Europe (Table 2), three insects ranged over large areas, covering several countries, but had strict ecological requirements. Two species of Plecoptera were associated with large lowland rivers where suitable habitats have been fragmented and eventually destroyed by human activities (Zwick, 1992). The third species, the Diptera Thyreophora cynophila, was found exclusively on large mammal carcasses until the mid 1800s (Séguy, 1950). It is suspected that the extinction of this species could be due to changes in livestock management and improved carrion disposal following the Industrial Revolution in Europe. On a longer time scale, how- ever, its extinction is likely to have been caused by the impoverishment of the megafauna - in Europe, there are now too few large predators that leave large carcasses. Another wellknown example of a species threatened because of its ecological requirements is the leather beetle Osmoderma eremita, which resides in hollow deciduous trees and is classified as Vulnerable by the IUCN Red List. With modern forestry practices, hollow trees are seldom left standing, and the leather beetle is becoming rarer over most of its range (Ranius et al., 2005).

The information collected by Fauna Europaea does not include species' ecological requirements, so we cannot assess the extent of ecological rarity in Europe. There are tight relationships between species and their habitats, and some species can be highly restricted in their requirements, a characteristic that increases their vulnerability because a single change in the habitat can have devastating effects on such species. The extreme case of habitat specialization is shown by host-specific species, and in particular parasitic species. No documented case of parasite extinction exists in Europe, but some parasitic species are known to be threatened because of their host being itself threatened (Stork and Lyal, 1993), and there are examples outside Europe of host-specific parasite species which became extinct after the extinction of their host (Mey, 2005). In Europe, extinct mammals and birds most probably had host-specific lice (Phthiraptera), which went extinct with their host. In particular, the great auk Pinguinus impennis must have had lice of the genus Austromenopon, Mjoberginirmus and Saemundssonia, as Alcidae regularly host these genera, with host-specific species (Price et al., 2003).

Accurate data on the proportion of host-specific species in insect communities are scarce. It varies among taxonomic groups and ecosystems, between $5 \%$ of the phytophagous 
beetle species being monophagous in a tropical rainforest (Basset et al., 1996), and 90\% of aphid species being highly host-specific (Dixon et al., 1987). Even with these somewhat imprecise figures on proportions of host specific species, their number in Europe reaches the thousands: taking the lowest figure given in the above references as a conservative estimate of host-specific species, i.e. $5 \%$, there would be at least 4600 host-specific species among the ca. 93,000 European insects, and certainly much more when parasitoid species are considered. Host-specific species representing the extreme case of ecological specialization, many more species can be considered as having strict ecological requirements. The 2010 target indicators should then include ecologically rare species. Special attention should be given to freshwater species which are known to be, on average, at higher risk of extinction than terrestrial ones (Revenga et al., 2005), and to cave species, which usually receive little attention in conservation strategies.

\subsection{Demographic rarity}

Species demonstrating demographic rarity are typically represented by large vertebrate predators, which occur naturally at low density (e.g. Slough and Mowat, 1996; Penteriani et al., 2002). Because of their low densities, these species can easily be eradicated from an area when they are hunted (Breitenmoser, 1998). This is the main form of rarity already represented in the indicators and in legal texts, with large vertebrates. However, invertebrates can experience demographic rarity as well, as is shown in the Red List where two thirds of the European species listed on demographic criteria are invertebrates (237 species). These invertebrate species Red Listed on demographic criteria could be a starting point for the selection of demographically rare species for the 2010 target indicators.

\section{Conclusion}

Our aim while writing this paper was to highlight that current indicators do not cover the species most at risk of extinction: currently, most categories of rare species are not in focus for the assessment of progress toward the 2010 target. Existing indicators deliver important informations on biodiversity trends (Julliard et al., 2004; Butchart et al., 2005; De Heer et al., 2005), but there is a need to develop alternative indicators dealing with rare species, which would complement informations already existing with a focus on the most threatened species. Funding is scarce and we are running out of time if the assessment of the progress towards the 2010 target is to be made before 2010, but assessing the success (or the failure) of the 2010 biodiversity target requires that the indicators cover a representative subsample of biodiversity (Balmford et al., 2005), with common and rare species. However, the main practical reason for choosing a species as indicator is the availability and quality of data attached to this species: birds are overrepresented in the various indices because they constitute the best known taxonomic group, with updated data gathered by thousands of people all over the world. Except for birds and a few other groups (large mammals, butterflies) or a scattering of individual species that are not necessarily representative of the whole European fauna, data on abundance, distribution and conservation status are difficult to find for most species. Indeed, the main argument against using rare species in indicators is their practical usefulness, i.e. data availability.

We did not address the issue of the composition of the alternative indicator, which would need at least another paper, but we give below some elements in this respect. The choice of indicator species needs a rigorous evaluation based on several parameters, including rarity. Ideally, a subsample of the European biodiversity to be used as indicators would be a set of species randomly picked from the European fauna. It should be stratified according to realms, biomes, ecosystems and taxonomic groups (Butchart et al., 2005). In any case, the indicator should avoid taxonomic bias, i.e. not over-represent vertebrates. Composite indices (e.g. Butchart et al., 2004; De Heer et al., 2005; Loh et al., 2005; Maes and Van Dyck, 2005) should be used, and the stratification should take into account the different forms of rarity, which appear to be a major characteristic of biodiversity.

When data are missing, targeted species should be chosen for monitoring, and the data that do not exist yet have to be gathered for this purpose. Choosing these target species must be done by specialists, i.e. taxonomists, who have the best available knowledge on ranges, vulnerability and ecological preferences of rare species. Data on the extent of distribution should be used when available; if not, a surrogate is given by Fauna Europaea distribution data. A threshold on the extent of range could be used to define geographically rare species to be used as indicators. Although there is no comprehensive database on species ecological needs, information about ecology, e.g. host plant preference of phytophagous insects, are documented for a large number of species, and these should be used when selecting ecologically rare species. Ecologically rare species could also be randomly picked in groups known to include species with strict ecological requirements (e.g. aquatic arthropods, old-growth forest dwellers, large carnivore parasites, cave species).

This data gathering will have a financial cost, since rare species, usually narrow-range invertebrates, need to be surveyed by specialists who know how to find and identify them. Current indicators (mainly birds, mammals, butterflies) have the advantage that they do not need highly specialized people to be monitored. However, as they tend to be wide-range species, they need to be surveyed by a large number of people for the data to be reliable (a large number of days/person is necessary). On the contrary, endemics, which need qualified people, can be surveyed with a much smaller number of days/ person, as they have short ranges. They are then comparatively cheaper to survey than wide-range ones.

The most well-known species, terrestrial vertebrates and butterflies (1523 species in Europe) constitute the bulk of current indicator species (e.g. Butchart et al., 2004; De Heer et al., 2005; Loh et al., 2005). The overlap between these and the 560 Red Listed European taxa is small, 98 species only being both Red Listed and indicator: this represents $6.4 \%$ of the indicator species being considered as threatened by the IUCN. Similar results about the low overlapping between Red Listed and indicator species have been found for cryptogams (Paltto et al., 2006). On the other hand, ca. half of these 1523 indicator species are protected by the European directives: indicator species (i.e. terrestrial vertebrates and butterflies) are more 
representative of protected species than of threatened species. With the indicators currently chosen, we could loose a significant number of species by 2010 and all these extinctions could go unnoticed. It is therefore essential to add new indicators or change the target.

\section{Author contributions}

B. Fontaine and P. Bouchet contributed to the ideas and methodology developed in this paper. B. Fontaine analyzed the data and wrote the paper. O. Gargominy designed the database used to handle the data. W. Bogdanowicz, P. Bouchet, H. Enghoff, D. Goujet, and W. Los, as members of the management team, lead the Fauna Europaea project. G. Boxshall, A. Minelli, and M. Ramos were members of the Fauna Europaea taxonomic advisory group. Y. de Jong, V. Michelsen, N. Bailly, P. Chylarecki, from the Fauna Europaea Project Bureau, collated the taxonomic and geographical information from the Group Coordinators. K. van Achterberg, M.A. Alonso-Zarazaga, R. Araujo, U. Aspöck, P. Audisio, B. Aukema, N. Bailly, M. Balsamo, R.A. Bank, P. Barnard, C. Belfiore, W. Bogdanowicz, T. Bongers, G. Boxshall, D. Burckhardt, J.-L. Camicas, P. Crucitti, L. Deharveng, A. Dubois, H. Enghoff, A. Faubel, R. Fochetti, D. Gibson, R. Gibson, M.S. Gómez López, M.S. Harvey, K.-G. Heller, P. van Helsdingen, H. Hoch, H. de Jong, O. Karsholt, L. Lundqvist, W. Magowski, R. Manconi, J. Martens, J.A. Massard, G. Massard-Geimer, S.J. McInnes, V. Michelsen, L.F. Mendes, E. Mey, A. Minelli, C. Nielsen, J.M. Nieto Nafría, E.J. van Nieukerken, J. Noyes, T. Pape, H. Pohl, W. De Prins, C. Ricci, C. Roselaar, E. Rota, A. SchmidtRhaesa, H. Segers, R. zur Strassen, A. Szeptycki, J.-M. Thibaud, A. Thomas, T. Timm, J. van Tol, W. Vervoort, R. Willmann, as Group Coordinators, collated the data on their respective groups (see details on http://www.faunaeur.org/experts.php). M. Asche collated the data on Hemiptera Fulgoromorpha and Cicadomorpha.

\section{Acknowledgements}

We thank Melina Verbeek, Fedor Steeman and Claire Basire (Fauna Europaea Project Bureau), and Anastasios Legakis, Trudy Brannan and Alfonso Navas Sanchez (Fauna Europaea Steering Committee) for their assistance in the implementation of the Fauna Europaea project. Grateful acknowledgements to Grégoire Lois (MNHN) who helped with the listing of protected species, and to Maurice Kottelat who provided invaluable data on extinct and threatened fish.

\section{Appendix. Authors contact information}

Benoît Fontaine

Muséum national d'Histoire naturelle

Département Systématique et Evolution - Malacologie USM 602

Case postale $\mathrm{N} 51$

57 rue Cuvier

75231 Paris Cedex 05, France

fontaine@mnhn.fr

Philippe Bouchet

Muséum national d'Histoire naturelle
Département Systématique et Evolution - Malacologie USM 602

Case postale $\mathrm{N} 51$

57 rue Cuvier

75231 Paris Cedex 05, France

pbouchet@mnhn.fr

Kees van Achterberg

Department of Entomology

Nationaal Natuurhistorisch Museum

Postbus 9517, 2300 RA Leiden, Netherlands

achterberg@naturalis.nnm.nl

Miguel Angel Alonso-Zarazaga

Depto. de Biodiversidad y Biología Evolutiva

Museo Nacional de Ciencias Naturales

Jose Gutierrez Abascal, 2

E-28006 Madrid, Spain

zarazaga@mncn.csic.es

Rafael Araujo

Museo Nacional de Ciencias Naturales

Jose Gutierrez Abascal, 2

E-28006 Madrid, Spain

mcnra2f@mncn.csic.es

Manfred Asche

Museum für Naturkunde

Institut für Systematische Zoologie

Humboldt Universität zu Berlin

Invalidenstrasse 43

10115 Berlin, Germany

manfred.asche@museum.hu-berlin.de

Ulrike Aspöck

Naturhistorisches Museum Wien

Universität Wien

2. Zoologische Abteilung

Burgring 7

1014 Wien, Austria

ulrike.aspoeck@nhm-wien.ac.at

Paolo Audisio

Dipartimento di Biologia Animale e dell'Uomo

(sezione Zoologia)

Viale dell'Università 32

00185 Rome, Italy

paolo.audisio@uniroma1.it

Berend Aukema

Kortenburg 31

NL-6871 Renkum, Netherlands

baukema@hetnet.nl

Nicolas Bailly

Muséum National d'Histoire Naturelle

Laboratoire d'Ichtyologie 
43 rue Cuvier

75231 Paris, France and

WorldFish Center, Natural Resource Management, Philippine Office Khush Hall, IRRI College, Los Baños, Laguna 4031, Philippines WorldFish Center contribution no. 1830 n.bailly@cgiar.org

\section{Maria Balsamo}

Istituto di Scienze Morfologiche

Università di Urbino 'Carlo Bo'

Sezione di Zoologia

via Oddi, 21

61029 Urbino, Italy

balsamo@uniurb.it

Ruud A. Bank

Graan voor Visch 15318

2132 EL Hoofddorp, Netherlands

r.bank@wxs.nl

Peter Barnard

Entomology Department

The Natural History Museum, Cromwell Road,

London SW7 5BD, UK

p.barnard@nhm.ac.uk

Carlo Belfiore

Instituto e Museo di Zoologia

Università di Napoli

Via Mezzocannone 8

80134 Napoli, Italy

carbelfi@unina.it

Wieslaw Bogdanowicz

Museum \& Institute of Zoology PAS

Wilcza 64

00-679 Warszawa, Poland

wieslawb@miiz.waw.pl

\section{Tom Bongers}

Wageningen Universiteit

Laboratory of Nematology

P.O. Box 8123

6700ES Wageningen, Netherlands

Tom.Bongers@wur.nl

Geoffrey Boxshall

Department of Zoology,

The Natural History Museum,

Cromwell Road

London SW7 5BD, UK

g.boxshall@nhm.ac.uk

Daniel Burckhardt

Naturhistorisches Museum
Augustinergasse 2

CH-4001 Basel, Switzerland

Daniel.Burckhardt@unibas.ch

Jean-Louis Camicas

IRD Centre de Montpellier

Dpt. Santé

B.P. 5045

34032 Montpellier, France

J-Louis.Camicas@mpl.ird.fr

Przemek Chylarecki

Museum and Institute of Zoology, PAS

Wilcza 64

PL-00-679 Warszawa, Poland

pch@miiz.waw.pl

Pierangelo Crucitti

Società Romana di Scienze Naturali (SRSN)

Via Fratelli Maristi 43

00137 Roma, Italy

srsn@libero.it

Louis Deharveng

Museum National d'Histoire Naturelle Paris

Laboratoire d'Entomologie

45, rue Buffon

75005 Paris, France

deharven@mnhn.fr

Alain Dubois

Muséum National d'Histoire Naturelle

Laboratoire de Zoologie Reptiles \& Amphibiens

25 rue Cuvier

75005 Paris, France

adubois@mnhn.fr

Henrik Enghoff

Natural History Museum of Denmark

University of Copenhagen, Universitetsparken 15, 2100 Koebenhavn OE, Denmark

HEnghoff@snm.ku.dk

Anno Faubel

Institute of Hydrobiology and Fisheries Science

University of Hamburg

Zeiseweg 9

22765 Hamburg, Germany

faubel@uni-hamburg.de

Romolo Fochetti

Università degli Studi della Tuscia

Dipartimento di Scienze Ambientali

Via S. Camillo de Lellis

01100 Viterbo, Italy

fochetti@unitus.it 
Olivier Gargominy

Muséum national d'Histoire naturelle

Département Systématique et Evolution - Malacologie USM 602

Case postale N 51

57 rue Cuvier

75231 Paris Cedex 05, France

gargo@mnhn.fr

David Gibson

The Natural History Museum

Parasitic Worms Division

Cromwell Road

London SW7 5BD, UK

dig@nhm.ac.uk

\section{Ray Gibson}

John Moores University

School of Biological and Earth Sciences

Byrom Street

Liverpool L3 3AF, UK

besrgibs@livjm.ac.uk

Maria Soledad Gómez López

Laboratori de Parasitologia

Universitat de Barcelona

Facultad Farmacia

Avd. Joan XXIII s/n

08028 Barcelona, Spain

msgomez@farmacia.far.ub.es

Daniel Goujet

Muséum National d'Histoire Naturelle

Dépt. Histoire de la Terre

8 , rue Buffon

75005 Paris, France

goujet@mnhn.fr

Mark S. Harvey

Dept. of Terrestrial Invertebrates

Western Australian Museum

Locked Bag 49

Welshpool DC, WA 6986, Australia

mark.harvey@museum.wa.gov.au

Klaus-Gerhard Heller

Institut für Zoologie

University of Erlangen-Nürnberg

Department of Zoology II

Staudstrasse 5

91058 Erlangen, Germany

kheller@biologie.uni-erlangen.de

Peter van Helsdingen

Nationaal Natuurhistorisch Museum Naturalis

European Invertebrate Survey
Darwinweg 2

2333 CR Leiden, Netherlands

Helsdingen@naturalis.nnm.nl

Hannelore Hoch

Museum für Naturkunde

Institut für Systematische Zoologie

Humboldt-Universität

Invalidenstr. 43

D-10115 Berlin, Germany

hannelore.hoch@museum.hu-berlin.de

Herman de Jong

Zoological Museum

University of Amsterdam

Department of Entomology

Plantage Middenlaan 64

1018 DH Amsterdam, Netherlands

hjong@science.uva.nl

Yde de Jong

Zoological Museum

University of Amsterdam

Faculty of Science

P.O. Box 94766

1090 GT Amsterdam, Netherlands

yjong@science.uva.nl

Ole Karsholt

Zoologisk Museum

University of Copenhagen

Det Naturvidenskabelige Fakultet

3. Afdeling (Entomologi)

Universitetsparken 15

2100 Koebenhavn OE, Denmark

OKarsholt@snm.ku.dk

Wouter Los

Zoological Museum

University of Amsterdam

Faculty of Science

P.O. Box 94766

1090 GT Amsterdam, Netherlands

los@science.uva.nl

Lars Lundqvist

Division of Systematic Zoology

Lund University

Helgonavägen 3

22362 Lund, Sweden

lars.lundqvist@zool.lu.se

Wojciech Magowski

A. Mickiewicz University

Department of Animal Taxonomy \& Ecology

Umultowska 89, PL- 61- 614 Poznan, Poland

magowski@amu.edu.pl 
Renata Manconi

Universita di Sassari

Dipartimento di zoologia e genetica evoluzionistica

Via Muroni, 25

07100 Sassari, Italy

rmanconi@ssmain.uniss.it

Jochen Martens

Institut für Zoologie

Johannes Gutenberg-Universität

Abteilung 1

Saarstrasse 21

D-55099 Mainz, Germany

martens@mail.uni-mainz.de

Jos A. Massard

1A Rue des Romains

L-6478 Echternach, Luxembourg

jmassard@pt.lu

Gaby Massard-Geimer

1A Rue des Romains

L-6478 Echternach, Luxembourg

jmassard@pt.lu

Sandra J. McInnes

British Antarctic Survey

Madingley Road

Cambridge, CB3 OET, UK

SJMC@bas.ac.uk

Luis F. Mendes

Instituto de Investigacào Cientifica Tropical

Centro de Zoologia

R.da Junquiera, 14

1300 Lisboa, Portugal

czool@iict.pt

Eberhard Mey

Naturhistorisches Museum im Thüringer Landesmuseum

Heidecksburg

Schlossbezirk 1

07407 Rudolstadt, Germany

mey-rudolstadt@t-online.de

Verner Michelsen

Zoologisk Museum

University of Copenhagen

Det Naturvidenskabelige Fakultet

Universitetsparken 15

2100 Koebenhavn OE, Denmark

vmichelsen@snm.ku.dk
University of Padova

Via Ugo Bassi 58 B

35131 Padova ITALY

alessandro.minelli@unipd.it

Claus Nielsen

Zoologisk Museum

University of Copenhagen

Det Naturvidenskabelige Fakultet

Universitetsparken 15

2100 Koebenhavn OE, Denmark

cnielsen@zmuc.ku.dk

Juan M. Nieto Nafría

Universidad de León

Departamento de Biología Animal

Campus de Vegazana

24071 León, Spain

dbajnn@unileon.es

Erik J. van Nieukerken

Nationaal Natuurhistorisch Museum Naturalis

P.O. Box 9517

2300 RA Leiden, Netherlands

Nieukerken@naturalis.nnm.nl

John Noyes

The Natural History Museum

Department of Entomology

Cromwell Road

London SW7 5BD, UK

j.noyes@nhm.ac.uk

Thomas Pape

Zoologisk Museum

University of Copenhagen

Det Naturvidenskabelige Fakultet

Universitetsparken 15

2100 Koebenhavn OE, Denmark

TPape@snm.ku.dk

Hans Pohl

Institut für Biodiversitätsforschung

Universität Rostock

Universitätsplatz 2-5

18051 Rostock, Germany

hans.pohl@uni-jena.de

Willy De Prins

Flemish Entomological Society

Diksmuidelaan 176

2600 Antwerpen, Belgium

willy.de.prins@telenet.be

Marian Ramos

Dept. biodiversidad y biologia evolutiva 
Museo Nacional de Ciencias Naturales

Jose Gutierrez Abascal, 2

28006 Madrid, Spain

m.ramos@mncn.csic.es

Claudia Ricci

Università degli Studi di Milano

Dipartimento di Biologia

Via Celoria 26

20133 Milano, Italy

claudia.ricci@unimi.it

Cees Roselaar

Zoological Museum Amsterdam

University of Amsterdam

P.O. Box 94766

Mauritskade 61

1090 GT Amsterdam, Netherlands

roselaar@mail.science.uva.nl

Emilia Rota

Dipartimento di Scienze Ambientali

Sezione di Sistematica ed Ecologia animale

e vegetale

Università di Siena

Via P. A. Mattioli 4

IT-53100 Siena, Italy

rota@unisi.it

Andreas Schmidt-Rhaesa

Zoological Museum

University of Hamburg

Martin-Luther-King-Platz 3

20146 Hamburg, Germany

a.schmidt-rhaesa@uni-bielefeld.de

Hendrik Segers

Freshwater Laboratory

Royal Belgian Institute for natural Sciences

Vautierstraat 29

B - 1000 Brussels, Belgium

hendrik.segers@naturalsciences.be

Richard zur Strassen

Entomologie I

Forschungsinstitut Senckenberg

Senckenberg-Anlage 25

60325 Frankfurt am Main, Germany

rizustra@sng.uni-frankfurt.de

Andrzej Szeptycki

Institute of Animal Systematics and Evolution

Polish Academy of Sciences

ul. Sławkowska 17

31-016 Kraków, Poland

SZEPTYCKI@isez.pan.krakow.pl
Jean-Marc Thibaud

Museum National d'Histoire Naturelle Paris-CNRS

ESA 8043

Laboratoire d'Entomologie

45 , rue Buffon

75005 Paris, France

thibaud@mnhn.fr

Alain Thomas

Laboratoire d'Hydrobiologie

Université Paul Sabatier UPS

118 rue de Narbonne

31062 Toulouse, France

alain3d@cict.fr

Tarmo Timm,

Estonian Agricultural University, Institute of Zoology

and Botany

Võrtsjärv Limnological Station

61101 Rannu, Tartumaa, Estonia

ttimm@zbi.ee

Jan van Tol

Nationaal Natuurhistorisch Museum Naturalis

P.O. Box 9517

2300 RA Leiden, Netherlands

Tol@naturalis.nnm.nl

Wim Vervoort

Nationaal Natuurhistorisch Museum Naturalis

P.O. Box 9517

2300 RA Leiden, Netherlands

vervoort@naturalis.nnm.nl

Rainer Willmann.

Institut für Zoologie und Anthropologie

Abteilung für Morphologie und Systematik und Museum

Berliner Str.28

37073 Göttingen, Germany

rwillma1@gwdg.de

R E F E R E N C E S

Afonso, O.M., Mateo, J.A., 2003. Conservación creativa de poblaciones mínimas El caso de los lagartos gigantes canarios. In: Jiménez, I., Delibes, M. (Eds.), Al Borde de la Extinción: Integrando Ciencia Política y Sociedad en la Recuperación de Especies Amenazadas. EVREN, Valencia, pp. 135-158.

Audisio, P., De Biase, A., Antonini, G., 2003. A new exceptional Meligethes of the $M$. aeneus species-group from Western Alps and an updated key to identification of M. aeneus and allied species (Coleoptera: Nitidulidae: Meligethinae). Insect Systematics et Evolution (Group 2) 34, 121-130.

Audisio, P., De Biase, A., Jäch, M., 1996. The Greek species of the genus Hydraena (subgenus Haenydra Rey) (Coleoptera, Hydraenidae). Aquatic Insects 18, 65-90. 
Balmford, A., Crane, P., Dobson, A., Green, R.E., Mace, G.M., 2005. The 2010 challenge: data availability, information needs and extraterrestrial insights. Philosophical Transactions of the Royal Society - Biological Sciences 360, 221-228.

Banarescu, P., 1994. The present-day conservation status of the fresh water fish fauna of Romania. Ocrotirea Naturii si a Mediului Inconjurator 38, 5-20.

Basset, Y., Samuelson, G.A., Allison, A., Miller, S.E., 1996. How many species of host-specific insects feed on a species of tropical tree? Biological Journal of the Linnean Society 59, 201-216.

Beaman, M., Madge, S., 1998. The Handbook of Bird Identification for Europe and the Western Palearctic. Christopher Helm, London.

Birdlife International, 2000. Threatened Birds of the World. Lynx Edicions and BirdLife International, Barcelona, Spain and Cambridge, UK.

Bouchet, P., 2006. Valid until synonymized, or invalid until proven valid? A response to Davis (2004) on species check-lists. Malacologia 48, 311-319.

Breitenmoser, U., 1998. Large predators in the Alps: the fall and rise of man's competitors. Biological Conservation 83, 279-289.

Butchart, S.H.M., Stattersfield, A.J., Baillie, J., Bennun, L.A., Stuart, S.N., Akcakaya, H.R., Hilton-Taylor, C., Mace, G.M., 2005. Using Red List Indices to measure progress towards the 2010 target and beyond. Philosophical Transactions of the Royal Society Biological Sciences 360, 255-268.

Butchart, S.H.M., Stattersfield, A.J., Bennun, L.A., Shutes, S.M., Akçakaya, H.R., Baillie, J.E.M., Stuart, S.N., Hilton-Taylor, C., Mace, G.M., 2004. Measuring global trends in the status of biodiversity: Red List Indices for birds. PLOS Biology 2, 1-11.

Convention on Biological Diversity, 2001a. 2010 Biodiversity Target. <http://www.biodiv.org/2010-target/default.asp> (accessed 20.10.05).

Convention on Biological Diversity, 2001b. The 2010 Biodiversity Target-Indicators. <http://www.biodiv.org/2010-target/ indicators.aspx> (accessed 20.10.05).

De Heer, M., Kapos, V., Ten Brink, B.J.E., 2005. Biodiversity trends in Europe: development and testing of a species trend indicator for evaluating progress towards the 2010 target. Philosophical Transactions of the Royal Society - Biological Sciences 360, 297-308.

Deharveng, L., Thibaud, J.M., 1989. Bessoniella procera n. g., n. sp. nouvel Orchesellidae cavernicole relictuel des Pyrenees (Insecta, Collembola). Bulletin Du Museum National D'histoire Naturelle Section A 11, 397-405.

Dixon, A.F.G., Kindlmann, P., Leps, J., Holman, J., 1987. Why there are so few species of aphids, especially in the tropics. The American Naturalist 129, 580-592.

Dobson, F.S., Yu, J., Smith, A.T., 1995. The importance of evaluating rarity. Conservation Biology 9, 1648-1651.

Dunn, R.R., 2005. Modern insect extinctions, the neglected majority. Conservation Biology 19, 1030-1036.

European Union, 2001. Presidency conclusions, Göteborg European Summit, 15-16 June 2001. <http://www.eu2001.se/ static/pdf/eusummit/conclusions_eng.pdf> (accessed 20.10.05).

Falkner, G., Ripken, T.E.J., Falkner, M., 2002. Mollusques Continentaux de la France: Liste de Référence Annotée et Bibliographie. Muséum national d'Histoire naturelle, Paris.

Fauna Europaea, 2004. Fauna Europaea database. http:// www.faunaeur.org/ (accessed 10.01.05).

Freyhof, J., Kottelat, M., 2005. Salvelinus evasus sp. n., a charr from deep waters of Lake Ammersee, southern Germany (Teleostei: Salmonidae), with comments on two extinct species. Revue Suisse de Zoologie 112, 253-269.

Freyhof, J., Schöter, S., 2005. The houting Coregonus oyrinchus (L.) (Salmoniformes: Coregonidae), a globally extinct species from the North Sea basin. Journal of Fish Biology 67, 713-729.

Fuller, E., 1987. Extinct Birds. Viking/Rainbird, London.

Galvagni, A., 2004. On the types of Anonconotus apenninigenus and on the locus typicus of this species (Orthoptera Tettigoniidae). Memorie della Societa Entomologica Italiana 82, 493-502.

Gaston, K.J., 1994. Rarity. Chapman et Hall, London.

Harrison, I.J., Stiassny, M.L.J., 1999. The quiet crisis: a preliminary listing of the freshwater fishes of the world that are extinct or missing in action. In: Macphee, R.D.E. (Ed.), Extinctions in Near Time: Causes, Contexts and Consequences. Kluwer Academic et Plenum Publishers, New York, Boston, pp. 271-331.

Harvey, M.S., 2002. Short-range endemism among the Australian fauna: some examples from non-marine environments. Invertebrate Systematics 16, 555-570.

Heurtault, J., 1994. Pseudoscorpions. In: Juberthie, C., Decu, V. (Eds.), Encyclopaedia biospeologica. Société de Biospéologie, Moulis and Bucarest, pp. 185-196.

IUCN, 1994. Guidelines for Protected Area Management Categories. CNPPA with the assistance of WCMC, IUCN, Gland, Switzerland and Cambridge, UK.

IUCN, 2006. 2006 IUCN Red List of Threatened Species. http:// www.redlist.org (accessed 15.05.06).

Julliard, R., Jiguet, F., Couvet, D., 2004. Common birds facing global changes: what makes a species at risk? Global Change Biology 10, 148-154.

Kottelat, M., 1997. An heuristic checklist of the freshwater fishes of Europe (exclusive of former USSR), with an introduction for non-systematists and comments on nomenclature and conservation. Biologia, Bratislava 52, 1-271.

Kottelat, M., Bogutskaya, N.G., Freyhof, J., 2005. On the migratory Black Sea lamprey and the nomenclature of the ludoga, Peipsi and ripus whitefishes (Agnatha: Petromyzontidae; Teleostei: Coregonidae). Zoosystema Rossica 14, 181-186.

Lamoreux, J., Akcakaya, H.R., Bennun, L., Collar, N.J., Boitani, L., Brackett, D., Brautigam, A., Brooks, T.M., Da Fonseca, G.A.B., Mittermeier, R.A., Rylands, A.B., Gardenfors, U., Hilton-Taylor, C., Mace, G., Stein, B.A., Stuart, S., 2003. Value of the IUCN Red List. Trends in Ecology and Evolution 18, 214-215.

Loh, J., Green, R.E., Ricketts, T., Lamoreux, J., Jenkins, M., Kapos, V., Randers, J., 2005. The Living Planet Index: using species population time series to track trends in biodiversity. Philosophical Transactions of the Royal Society - Biological Sciences 360, 289-295.

Lumaret, J.P., Lobo, J.M., Jay-Robert, P., 1996. Catalogue et Atlas des Scarabeides Laparosticti Endémiques de France. IEGB-SPN/ MNHN, OPIE, Paris.

Maes, M., Van Dyck, H., 2005. Habitat quality and biodiversity indicator performances of a threatened butterfly versus a multispecies group for wet heathlands in Belgium. Biological Conservation 123, 177-187.

Mauries, J.-P., 1986. Un diplopode cavernicole relictuel des Alpes calcaires suisses: niphatrogleuma wildbergeri, n. g., n. sp. (Craspedosomida, Cleidogonoidea). Revue Suisse de Zoologie 93, 249-256.

Menier, J.J., 2002. Thyreophora cynophila (Diptera, Thyreophoridae) has disappeared from France! What's the police doing? In: Proceedings of the First European Forensic Entomology Seminar. OISIN, p. 114.

Mey, E., 2005. Psittacobrosus bechsteini: a new extinct chewing louse (Insecta, Phthiraptera, Amblycera) off the Cuban macaw Ara tricolor (Psittaciiformes), with an annotated review of fossil and recently extinct animal lice. Anzeiger des Vereins Thueringer Ornithologen 5, 201-217.

Myers, N., Mittermeier, R.A., Mittermeier, C.G., Da Fonseca, A.B., Kent, J., 2000. Biodiversity hotspots for conservation priorities. Nature 403, 853-858. 
Nalbant, T.T., Otel, V., 1995. Knipowitschia cameliae (Pisces: Gobiidae) a new species of dwarf gobies from the panizzae group. Some problems of its protection. Ocrotirea Naturiisi a Mediului Înconjurator 39, 51-57.

Palmer, M.A., Covich, A.P., Finlay, B.J., Gibert, J., Hyde, K.D., Johnson, R.K., Kairesalo, T., Lake, S., Lovell, C.R., Naiman, R.J., Ricci, C., Sabater, F., Strayer, D., 1997. Biodiversity and ecosystem processes in freshwater sediments. AMBIO 26, 571-577.

Paltto, H., Nordén, B., Götmark, F., Niklas, F., 2006. At which spatial and temporal scales does landscape context affect local density of Red Data Book and Indicator species? Biological Conservation 133, 442-454.

Penteriani, V., Gallardo, M., Roche, P., 2002. Landscape structure and food supply affect eagle owl (Bubo bubo) density and breeding performance: a case of intra-population heterogeneity. Journal of Zoology 257, 365-372.

Perrin, J.F., Bless, R., Nalbant, T.T., 1993. Romanichthys valsanicola, l'expédition de la dernière chance (octobre 1992, rivière Vilsan, Roumanie). Revue Française D'aquariologie 20, 37-40.

Price, R.D., Hellenthal, R.A., Palma, R.L., 2003. World checklist of chewing lice with host associations and keys to families and genera. In: Price, R.D., Hellenthal, R.A., Palma, R.L., Johnson, K.P., Clayton, D.H. (Eds), The Chewing Lice: World Checklist and Biological Overview, pp. 1-448.

Pucek, Z., Krasinska, M., Krashinski, Z.A., Olech, W. (Eds.), 2004. European Bison. Status Survey and Conservation Action Plan. IUCN/SSC Bison Specialist Group. IUCN, Gland, Switzerland and Cambridge, UK.

Rabinowitz, D., 1981. Seven forms of rarity. In: Synge, H. (Ed.), The Biological Aspects of Rare Plant Conservation. Wiley, Chichester, pp. 205-217.

Ranius, T., Aguado, L.O., Antonsson, K., Audisio, P., Ballerio, A., Carpaneto, G.M., Chobot, K., Gjurasin, B., Hanssen, O., Huijbregts, H., Lakatos, F., Martin, O., Neculiseanu, Z., Nikitsky, N.B., Paill, W., Pirnat, A., Rizun, V., Ruicanescu, A., Stegner, J., Suda, I., Szwalko, P., Tamutis, V., Telnov, D., Tsinkevich, V., Versteirt, V., Vignon, V., Vogeli, M., Zach, P., 2005. Osmoderma eremita (Scopoli, 1763) (Coleoptera: Scarabaeidae: Cetoniinae) in Europe: a short summary of a pan-European project. Latvijas Entomologs Supplementum 6, 79-82.

Revenga, C., Campbell, I., Abell, R., De Villiers, P., Bryer, M., 2005. Prospects for monitoring freshwater ecosystems towards the
2010 targets. Philosophical Transactions of the Royal Society Biological Sciences 360, 397-413.

Séguy, E., 1950. La biologie des diptères. Encyclopédie Entomologique Série A 26, 1-609.

Slough, B.G., Mowat, G., 1996. Lynx population dynamics in an untrapped refugium. Journal of Wildlife Management 60, 946961.

Solem, A., 1984. A world model of land snail diversity. In: Solem, A., Bruggen, A.C.V. (Eds.), World-wide Snails. Biogeographical Studies on Non-marine Mollusca. Backhuys Publisher, Leiden, pp. 6-22.

Stattersfield, A.J., Crosby, M.J., Long, A.J., Wege, D.C. (Eds.), 1998. Endemic Bird Areas of the World - Priorities for Biodiversity Conservation. Birdlife International, Cambridge.

Stork, N., Lyal, C.H.C., 1993. Extinction or 'co-extinction' rates? Nature 366, 307.

Stork, N.E., 1997. Measuring global biodiversity and its decline. In: Reaka-Kudla, M.L., Wilson, D.E., Wilson, E.O. (Eds.), Biodiversity II. Understanding and Protecting our Biological Resources. Joseph Henry Press, Washington, DC, pp. 41-68.

Thomas, J.A., 2005. Monitoring change in the abundance and distribution of insects using butterflies and other indicator groups. Philosophical Transactions of the Royal Society Biological Sciences 360, 339-357.

Tilman, D., Knops, J., Wedin, D., Reich, P., Ritchie, M., Siemann, E., 1997. The influence of functional diversity and composition on ecosystem processes. Science 277, 1300-1302.

Voisin, J.F. (Ed.), 2003. Atlas des Orthoptères (Insecta: Orthoptera) et des Mantides (Insecta: Mantodae) de France. Muséum national d'Histoire naturelle, Paris.

WCMC, 1998. Freshwater biodiversity: a preliminary global assessment. By Groombridge, B and Jenkins M. World Conservation Monitoring Centre - World Conservation Press, Cambridge.

Wilson, E.O., 1992. The Diversity of Life. Harvard University Press, Cambridge, MA.

Yu, J., Dobson, F.S., 2000. Seven forms of rarity in mammals. Journal of Biogeography 27, 131-139.

Zwick, P., 1992. Stream habitat fragmentation - a threat to biodiversity. Biodiversity and Conservation 1, 80-97.

Zwick, P., 2004. Key to the West Paleartic genera of stoneflies (Plecoptera) in the larval stage. Limnologica 34, 315-348. 